\title{
Nõukogudeaegse kõrgharidusega keskealised siirdeaja elukestva õppe keskkonnas
}

\author{
Tiiu Männiste ${ }^{\mathrm{al}}$ \\ a Tartu Ülikooli ühiskonnateaduste instituut
}

\begin{abstract}
Annotatsioon
Artikkel käsitleb 1950ndate lõpul ja 1960ndate esimesel poolel sündinud nõukogudeaegse kõrgharidusega spetsialistide kultuurilise kapitali uuendamist siirdeajal tööalases täiendus- ja ümberõppes osalemise kaudu. Kvalitatiivse uuringu tulemuste põhjal selgus, et nõukogudeaegse kõrgharidusega keskealiste praegune põlvkond suutis siirdeajal püsida aktiivses tööhõives suurel määral tänu osalemisele elukestvas õppes. Samas ei suutnud intervjueeritavad omandada siirdeaja baasoskusi (võõrkeel, arvutioskus) sellisel tasemel, mis annaks neile konkurentsieelise digitaalses ühiskonnas. Uurimistulemused võimaldavad väita, et keskealiste kõrgharidusega inimeste väheste baasoskuste põhjused peituvad suurel määral siirdeaja kultuuris, elukestva õppe poliitikas ja selle põlvkonna elukaare trajektoori katkestuses 1990ndate algul.
\end{abstract}

Võtmesõnad: siirdeaeg, elukestev õpe, õppijatüübid, elukaar, baasoskused

\section{Sissejuhatus}

Artiklis analüüsin, kuidas on 1950ndate lõpul ja 1960ndate esimesel poolel sündinud spetsialistid, kes on omandanud kõrghariduse nõukogude ajal, uuendanud oma kultuurilist kapitali elukestvas õppes osalemise kaudu. Selle põlvkonna elukäigule ja karjäärile avaldasid eriti suurt mõju siirdeajal toimunud radikaalsed majanduslikud ja poliitilised ümberkorraldused.

1980ndate lõpust alanud postkommunistlik transformatsioon ehk siire (transition) tähistab üleminekut sotsialistlikult formatsioonilt kapitalistlikule. Esmaste siirdeprotsessidena käsitletakse majanduslikke ja poliitilisi muutusi kogu Ida-Euroopa postsotsialistlikus maailmas (Lauristin \&

1 Ühiskonnateaduste instituut, sotsiaal- ja haridusteaduskond, Tartu Ülikool, Lossi 36, 51003

Tartu; tiiu.manniste@ut.ee 
Vihalemm, 2009). Postsotsialistliku siirde eripära ja tulemuste selgitamisel Eesti ühiskonnas kasutatakse sageli terminit katkestus, mis tähendab ,järjepidevuse puudumist poliitilises, ühiskondlikus, kultuurilises ja kogemuslikus plaanis" (Kõresaar, 2005, lk 69-70). Siinses artiklis vaatlen peamiselt uuritava rühma siirde-eelsel sotsiaalsel ja kultuurilisel kapitalil põhinevat töökarjääri katkestust ning selle uuendamist siirdeaja kultuurilise kapitali suurendamise kaudu. Uuritav rühm esindab siirdeaja eel tööturul kinnistunud mõneaastase töökogemusega professionaalide põlvkonda, kes kuulus reformide algperioodil 22-40-aastaste nooremate tööealiste rühma (Sugarman, 2001) ning on praeguseks jõudnud vanemasse keskikka (40-60-aastased). Need on üldjuhul inimesed, kes olid nõukogude ühiskonnas töös edukad, kusjuures nende „oluliseks eduressursiks oli erialane kõrgharidus, mis oli eelduseks kujuneda ka siirdeaja soodsaks stardikapitaliks" (Helemäe, Saar, \& Vöörmann, 2000, lk 273).

Elutee/-kaare teooriate järgi on igal põlvkonnal omad sotsiaalsed staatused, rollid ja arengusihid. Noorema tööealise põlvkonna elutee bioloogilisse ja sotsiaalsesse arengusse mahub tavaliselt nii perekonna loomine, töökarjääri kujunemine kui ka kindla elustiili omaksvõtt (Sugarman, 2001). Siirdeaja alguse radikaalsed reformid ohustasid eelkõige just noore täiskasvanuealiste põlvkonna elukaare trajektoori (Elder \& Shanahan, 2006).

Vaadeldava põlvkonna töökarjääri katkestuse mastaapsust iseloomustab siirdeaja alguse muutuste ulatus: postsotsialistlik maailm lülitus plaanimajanduslikust industriaalühiskonnast otse kõrgtehnoloogilisse infoühiskonda (Bell, 1999; Castells, 2000) ehk tehnoloogilis-majanduslikku paradigmasse (Perez, 2002). Seetõttu kujunes vaadeldava põlvkonna jaoks keeruliseks ülesandeks peale oma professionaalse pädevuse uuendamise ka Eestis 1990ndatel toimunud info- ja kommunikatsioonitehnoloogia (IKT) plahvatusliku arenguga kohanemine (Kattel \& Kalvet, 2002). Samal ajal globaliseerus seni suletud ühiskond väga kiiresti, millega kaasnes sisenemine ingliskeelsesse infovälja. Nende kahe protsessi, siirdeaja ümberkorralduste ja globaliseerumise ajaline kokkulangemine muutis vaatlusaluse põlvkonna jaoks ümberõppe vajaduse eriti pakiliseks, seda nii erialaste oskuste täiendamisel kui ka uute baasoskuste omandamisel.

\section{Uurimuse teoreetilised lähtekohad}

\section{Kultuuriline kapital siirdeajal}

Kõnesoleva uurimuse teoreetilises raamistikus on keskne koht Bourdieu kultuurilise kapitali mõistel. Kultuurilist kapitali on peetud vaimseks ressursiks, 
mida üksikisik võib aja jooksul oma võimete ja oskuste arendamise, koolituste ja kultuuritegevuse kaudu koguda (Bourdieu, 1984). Bourdieu eristab kultuurilise kapitali kolme vormi, mis on seotud indiviidiga (teadmised ja õpivalmidus), kultuurivaraga (raamatud, kvalifikatsioon jne) ja institutsioonidega (raamatukogud, haridusasutused).

Kultuurilise kapitali tähtsus „sotsiaalse ruumi” (Bourdieu, 2003, lk 31) taastootmises tuleb esile haridusinstitutsioonide kaudu. Bourdieu on siin silmas pidanud eeskätt kõrgemaid õppeasutusi, mis tagavad oma lõpetajatele sotsiaalse ruumi jaotusstruktuuris kindla positsiooni. Hea näide selle kohta on nõukogude aja haridussüsteemile iseloomulik suunamismehhanism, kus üleminek haridussüsteemist tööle toimus kindlate reeglite järgi: „Riik tegutses omamoodi väravavahina, kontrollides sotsiaalsete gruppide formeerumist" (Helemäe et al., 2000, lk 17). Kuna Nõukogude Liidus puudus klassikaline majanduslik kapital - tootmisvahendite eraomandus -, oli kultuuriline kapital (mille hulka kuulus tollal ka kohustuslik „,ideoloogiline teadlikkus") seda tähtsam. Nõukogudeaegset kõrgharidust võib mingil määral samastada bourdieuliku „haridusliku klassifikatsiooniaktina” (Bourdieu, 2003, lk 44), mis lõi võimaluse sotsiaalseks eristumiseks madalama taseme kultuurilise kapitali agentidest. Majandusliku, sotsiaalse ja kultuurilise kapitali eristusprintsiip hakkas postsotsialistlikes riikides klassikalisel viisil toimima alates siirdeajast koos üleminekuga turumajandusele.

1990ndate siirdeaja majanduse radikaalsete struktuurimuudatustega katkesid nõukogudeaegse hariduse ja töömaailma seosed. Toimimast lakkasid ka nõukogudeaegsed hariduse selekteerivad mehhanismid, „üleminekuaeg tõi kaasa põlvkondade võimaluste veelgi suurema diferentseerumise, sest koos raamtingimustega muutusid ka väärtused" (Helemäe et al., 2000, lk 14). Kapitalismi normatiivset üleolekut väärtustav siirdekultuur (Kennedy, 2002) eeldas uut laadi kultuurilist kapitali. Kuid kultuuriline kapital ei muutu kiiresti (Bourdieu, 1984, 2003; Schuller, 2001), mistõttu hangiti uuenenud kultuurilist kapitali ka varasematele oskustele ja teadmistele tuginedes. Seega toimis korraga nii vana kui ka uus kultuuriline kapital. Kuna siirdeaja muutuste kontekstis uus institutsionaalne tasand oli veel kujunemisjärgus, osutus vanade ja uute väärtuste põimumise ning uute hoiakute tekkimisega kaasneva kultuurilise kapitali uuendamine üsna keeruliseks (Kalmus \& Vihalemm, 2004; Kennedy, 2002).

Siinses uurimuses käsitlen kultuurilise kapitali vormidena vaatlusaluse rühma nõukogudeaegseid teadmisi ja valmisolekut uuesti õppida siirdeajal, kultuurivarana olemasolevat ja uut omandatud kvalifikatsiooni ning institutsioonidena siirdeaja elukestva õppe keskkondi (täiendus- ja ümberõppe kursused). Üheks nõukogudeaegse kultuurilise kapitali uuendamise 
inkubaatoriks Eestis kujunes 1990ndatel järsult suurenenud täiskasvanuhariduse koolitusturg, kus puudusid formaalharidusele omased ranged hierarhiad ja ordinatsiooniaktid (Märja, 2008).

\section{Elukestev õpe kui kultuurilise kapitali uuendamise võimalus}

Alates 20. sajandi teisest poolest haridusteoreetikute ja globaalsete rahvusvaheliste organisatsioonide (UNESCO, OECD) käivitatud haridusparadigma education across the lifespan (EAL, 'haridus igas elueas') on bourdieuliku traditsioonilise hariduse erisuste tegurid ja kultuurilise kapitali taastootmismehhanismid laiali jaotanud varasemast mitmekesisemale väljale, kus kehtib universaalse hariduskapitali (baasoskuste, võtmepädevuste) printsiip (Field, 2005; Jarvis, 2007; Rubenson, 2004). Bourdieu kirjeldatud haridusinstitutsioonide meritokraatlikku eristusmehhanismi püütakse uute globaalsete hariduspoliitiliste strateegiate abil asendada haridusideaalidega, mis põhinevad peamiselt võrdsustamise/tasandamise ja sotsiaalse õigluse printsiibil (Centeno, 2011).

1990ndate keskpaigaks oli „haridus igas elueas” arenenud õppijakeskseks uueks haridusparadigmaks ehk „elukestvaks õppeks” (lifelong learning) (Field, 2005; Jarvis, 2007), kus haridust ja õppimist peetakse tööprotsesside osaks. Elukestev õpe kui uus kultuurilise kapitali taastootmise väli sisaldab nii töömaailma kui ka haridussüsteemi koosmõju, seega kultuurilise ja majandusliku kapitali vahetuskurssi konverteeritakse laiemalt kui vaid formaalhariduslike eristusprintsiipide alusel (Bourdieu, 2003; Rubenson, 2004).

Kultuurilise kapitali uuendamise ja täiendamise keskkonnana kujunes elukestev õpe formaalharidusest paindlikumaks ja võimalusterohkemaks (Illeris, 2003; Jarvis, 2007; Quane, 2008). Hoolimata elukestva õppe idee pikast minevikust tunnustati seda diskursiivse poliitikana alles 1990ndate keskel, mil see kontseptsioon võeti riikliku hariduspoliitika tegevusprogrammidesse (Bélanger \& Federighi, 2000; Centeno, 2011). Siirdeaja alguseks oli elukestva õppe poliitilistes strateegiates välja kujunenud kahesuunalise kontseptsiooni piirjooned: üldine inimarengu idee ja majandusressursi arendamine. Selle kahe idee kandjad on kaks erineva suunitlusega rahvusvahelist organisatsiooni: UNESCO ja OECD (Quane, 2008; Rubenson, 2004; Schuller, 2008). Ühe ja sama haridusprintsiibi erinevad poliitilised edasiarendused peegeldavad ka erinevaid poliitilisi diskursusi: egalitaarne heaoluriigi versioon (UNESCO) näeb kohustuslikku koosmõju hariduse ja ühiskonna vahel; neoliberaalne versioon (OECD) rõhub õppimise individuaalsele vastutusele ja eeldab, et turg, hariduskorraldus ja 
õppimine tagavad inimese osalemise teadmistepõhises majanduses (ibid.). Eesti täiskasvanuhariduse tööalases ümber- ja täiendusõppes domineeris neoliberaalne majandusliku progressi aspekt (Holford, Riddell, \& Weedon, 2010; Quane, 2008; Rubenson, 2004; Schuller, 2008), mis poliitilise tegevusprogrammina väljendus 2005. aastal vastu võetud „Elukestva õppe strateegias" (Haridus- ja Teadusministeerium, 2005).

„Elukestva õppe mõisteid (õppivad kodanikud, õppivad linnad/piirkonnad, óppiv organisatsioon) kasutatakse riikide poliitikates eri määral” (Holford et al., 2010, lk 62). Tänapäeval üldtuntud termini elukestev õpe asemel kasutati Eesti 1990ndate täiskasvanuhariduse puhul terminit pidevõpe (Jarvis, 1998; Märja, 2008). 1993. aastast praeguseni kehtiva täiskasvanute koolituse seaduse järgi eristatakse Eestis nelja täiskasvanuhariduse koolitusliiki: taseme-, ümber-, tööalast täiendusõpet ja vabaharidust (Riigikogu, 1993). Siirdeaja majanduse struktuurimuudatuste ajal kujunesid täiskasvanute koolitusliikidest olulisemaks just tööalased koolitused.

Siinses artiklis jälgin kultuurilise kapitali uuendamist peamiselt tööalases täiendus- ja ümberõppes osalemise kaudu. Seejuures pööran põhitähelepanu siirdeajale iseloomulike uute baasoskuste (inglise keele ja arvutioskuse) omandamise viisidele ja tulemustele. Uurimuse põhiküsimusteks kujunesid: 1) millised olid siirdeaja kultuurilise kapitali uuendamise võimalused?

2) millist kultuurilist kapitali tootsid uued enesetäiendamise võimalused?

3) milliseks kujunesid õpihoiakud ja motivatsioon?

4) kuidas mõjutas kultuurilise kapitali uuendamine siirdeaja karjääriteid?

\section{Uuringu metoodika}

\section{Valim}

Intervjueeritavate valikul olid põhikriteeriumideks vanus (sünniaasta vahemikus 1955-1964) ja siirdeaja alguseks omandatud eestikeelne tehniline, põllumajanduslik või sotsiaalhumanitaarne kõrgharidus (tabel 1). Intervjueeritavate vanus siirdeperioodi algul $(1988)^{2}$ oli $25-34$ aastat, siirdeaja lõpuks (2008) 45-54 aastat. Siirdeaja alguseks oli vastajate nõukogudeaegne tööstaaž keskmiselt 3-5 aastat.

Valimi heterogeensuse tagab eri kõrgkoolidest saadud haridus ning eri töövaldkondades siirdeaja alguses omandatud töökogemus (tabel 1). Valimi 12 intervjueeritavat esindavad nõukogude aja kuuest Eesti kõrgkoolist viit (Tartu Riiklik Ülikool, Eesti Põllumajanduse Akadeemia, Tallinna

2 Siirdeaja perioodide arvestamisel lähtun Lauristini ja Vihalemma (2009) käsitlusest. 
Polütehniline Instituut, Pedagoogika Instituut, Eesti Riiklik Kunstiinstituut). Valimi sooline ja valdkondlik jagunemine kujunes järgmiseks: seitse naist, sh üks tehnilise, kaks põllumajandusliku ja neli sotsiaalhumanitaarse haridusega, ning viis meest, sh kolm tehnilise ja kaks põllumajandusliku haridusega. Sotsiaalse staatuse järgi kuuluvad neli intervjueeritavat (sh kolm meest) ettevõtjate ja kaheksa töövõtjate/palgatööliste hulka; 12-st neli olid ümber õppinud ja omandanud uue eriala.

Intervjueeritavad on pärit Eesti eri piirkondadest: Tallinnast (kaks), Viljandist (kolm), Haapsalust (kaks), Tartust (üks), Pärnumaalt (kaks), Viljandimaalt (üks) ja Harjumaalt (üks). Valimi kriteeriumidele vastavaid intervjueeritavaid otsisin kolmandate isikute kaudu. Ükski vastaja pole mulle kui uurijale lähedane isik. Uurijana teadsin kolme intervjueeritavat (kahte Viljandist ja ühte Tartust) kunagiste, 1990ndate alguse töökontaktide kaudu.

Tabel 1. Intervjueeritavate koodnimed, vanus, nõukogudeaegne haridus ja kõrgkoolijärgsed ametid

\begin{tabular}{l|l|l|l|l}
\hline $\begin{array}{l}\text { Intervjueeritava } \\
\text { koodnimi }\end{array}$ & Sugu & $\begin{array}{l}\text { Sünni- } \\
\text { aasta }\end{array}$ & $\begin{array}{l}\text { Lõpetatud } \\
\text { kõrgkool }\end{array}$ & Eriala, amet siirdeaja algul (1991) \\
\hline Toomas & Mees & 1961 & TPI & Vanemmeister, konstruktor \\
\hline Toivo & Mees & 1958 & TPI & Ehitusinsener \\
\hline Tarmo & Mees & 1956 & TPI & Trükikoja peainsener \\
\hline Taimi & Naine & 1956 & TPI & Puidutehnoloog \\
\hline Albert & Mees & 1960 & EPA & Sovhoosi peazootehnik \\
\hline Alex & Mees & 1960 & EPA & Sovhoosi peazootehnik \\
\hline Alice & Naine & 1957 & EPA & Metsakasvatuse vaneminsener \\
\hline Anna & Naine & 1960 & EPA & Sovhoosi zootehnik \\
\hline Siiri & Naine & 1961 & ERKI & Vabakutseline kunstnik \\
\hline Salme & Naine & 1959 & TRÜ & Ajalooõpetaja \\
\hline Silja & Naine & 1956 & TRÜ & Arst \\
\hline Silvi & Naine & 1958 & TPedl & Klubitöötaja \\
\hline
\end{tabular}

Märkused. 1. Intervjueeritavate nimed on tinglikud, nime algustäht viitab omandatud haridusele: T - tehniline, A - põllumajanduslik (agriculture), S - sotsiaalhumanitaarne. 2. Kõrgkoolide nimelühendid: TPI - Tallinna Polütehniline Instituut; EPA - Eesti Põllumajanduse Akadeemia; ERKI - Eesti Riiklik Kunstiinstituut; TRÜ - Tartu Riiklik Ülikool; TPedl - Pedagoogika Instituut. 


\section{Uurimismeetod}

Uurimismeetodina oli kasutusel poolstruktureeritud biograafiline intervjuu, mille eesmärk oli panna küsitletavad meenutama oma koolituskogemusi ja kirjeldama neid oma elu episoode, millel oli seos koolitustes osalemisega ja senise töökogemuse ümberhindamisega. Selle intervjuuvormi kasutamise lähtepunkt on oletus, et subjekti kogemused mingil alal on talletatud ning neid mäletatakse narratiiv-episoodilise ja semantilise teadmise kujul (Antikainen, 1996; Patton, 1990; Vogt, 2005).

2011. aasta maist novembrini kogusin 12 intervjuu käigus andmeid intervjueeritava osalemise kohta elukestvas õppes siirdeajal. Iga intervjuu kestus oli 1-1,5 tundi. Vastajad said võimaluse oma sõnadega lahti seletada nõukogudeaegsete oskuste ja teadmiste uuendamise protsesse erinevate situatsioonide ja episoodide jutustamise kaudu. Kuna siirdeaeg hõlmab ligi kahekümneaastast ajavahemikku, olid need jutustused tagasivaatavad ehk retrospektiivsed. Intervjueeritavad meenutasid õppimise seoseid oma töökarjääriga. Intervjuu kavas sisaldunud üldised teemad - nõukogudeaegsete teadmiste ja oskuste kasutamine ning elukestvas õppes osalemine siirdeajal - puudutasid kõiki intervjueeritavaid. Siinse uuringu ühe põhiküsimuse Kuidas elukestvas õppes osalemise kaudu muutub sotsiaalne staatus? tulemused selgusid intervjueeritavate vastustest järgmistele alaküsimustele:

- Palun meenutage, miks tekkis vajadus end täiendada või ümber õppida?

- Millistel tööalastel täiendus- ja ümberõppe, tasemeõpe ja vabahariduse koolitustel olete osalenud?

- Palun hinnake siirdeaja koolituste mõju töökoha muutustele. Mis põhjustel muutus Teie töökoht või eriala?

Andmete analüüsimisel lähtusin intervjueeritavate vastuste kodeerimisel sellest, milliseid elukestvas õppes osalemise vajadusi ja võimalusi intervjueeritavad väljendasid.

\section{Tekstianalüïs}

Intervjuude tekste analüüsisin kvalitatiivse sisuanalüüsi meetodil, seejuures rakendasin põhistatud teooriale omast käsitlusviisi (Tesch, 1990), st ei kasutanud etteantud analüüsikategooriaid, vaid tuletasin kategooriad uurimisküsimuste põhjal, üldistades induktiivselt erinevate vastajate tekstide kokkulangeva sisuga väidete tähendust.

Kodeerimisel kasutasin induktiivset analüüsimeetodit: intervjuudes sisaldunud andmetel põhinevad kategooriad kujunesid teksti aktiivse lugemise käigus. See induktiivne meetod võimaldab viia uurija nn varjatud andmestiku juurde, millest kujunevad teksti mitmekordse kodeerimise 
käigus analüüsikategooriad, mis võivad pakkuda uurijale olemasoleva teooria kõrvale uusi tõlgendusi ja arusaamu (Tesch, 1990). Analüüsiühikute korduva kodeerimise tulemusel selgusid need analüüsikategooriad, milles peegeldusid intervjueeritavate siirdeaja elukestvas õppes osalemise sarnased mustrid ja erinevad tingimused. Intervjuude keskseteks analüüsikategooriateks (tabel 2) kujunesid need transkribeeritud intervjuudes kirjeldatud kogemused, milles avaldusid õppesituatsioonid ja karjäärimuutused: õppimisega seotud tööalase toimetuleku tunnused ja siirdeaja baasoskuste taseme näitajad.

Tabel 2. Intervjuude tekstide peamised kvalitatiivse sisuanalüüsi kategooriad

\begin{tabular}{|c|c|}
\hline $\begin{array}{l}\text { Õppimisega seotud tööalase toimetuleku } \\
\text { tunnused }\end{array}$ & Siirdeaja baasoskuste taseme näitajad \\
\hline $\begin{array}{l}\text { Siirdeaja karjääriteed } \\
\text { Valmisolek õppimise kaudu kultuurilist } \\
\text { kapitali uuendada } \\
\text { Õppimisega kaasnenud hoiakud ja } \\
\text { motivatsioon, õppes osalemise tüübid }\end{array}$ & $\begin{array}{l}\text { Inglise keele omandamise viisid, } \\
\text { võimalused ja tulemused } \\
\text { Arvutioskuse omandamise viisid, } \\
\text { võimalused ja tulemused } \\
\text { Õppimisega kaasnenud hoiakud ja } \\
\text { motivatsioon }\end{array}$ \\
\hline
\end{tabular}

Üks kogutud andmete valiidsuse tagamise kriteeriume on intervjuude teemakohasus ja uurija pikaajaline viibimine uurimisväljal, samuti tulemuste etteaimamatus (Flick, 2009), mis avaldus ka selle uuringu puhul. Täiskasvanuhariduse statistiliste uuringute järgi osalevad kõrgharidusega keskealised aktiivselt elukestvas õppes (Kailis \& Pilos, 2005; Reinhold, 2012; Statistikaamet, 2009). Artikli tulemuste järgi see muster ei sobi, sest valimi hulka sattus intervjueeritavaid, kes polnud osalenud ühelgi täiendusõppe koolitusel. Tänu sellistele andmetele kujunes tulemuste analüüs mitmekihilisemaks ja pakkus uusi vaatenurki.

\section{Uuringu tulemused}

Artikli uurimistulemuste osas tutvustan siirdeaja intervjueeritavate tööalastes koolitustes osalemist ja õppimisega seotud karjääriteid (tabel 3), siirdeaja esmaste baasoskuste (võõrkeele, arvutioskuste) omandamise protsesse ja tulemusi ning erinevaid õppijatüüpe, mis selgusid õpihoiakute põhjal (tabel 4). 


\section{Kultuurilise kapitali uuendamine ja karjääriteed}

Siirdeaja 1990ndate alguse koolitusi puudutavates vastustes peegeldusid tollased radikaalsed muutused majanduse struktuuris. Näiteks kaasnes põllumajandustootmise restruktureerimisega põllumajanduse ja sellega seotud valdkondades tööhõive järsk vähenemine: ajavahemikus 1990-1995 oli keskmine hõivatute arvu vähenemise määr aastas 16,9\% (Viira, 2011). Seetõttu tekkis vajadus ümberõppe järele eelkõige endistel põllumajandusspetsialistidel. Turumajanduse väljakujunemisel vajasid ka eraettevõtlusse siirdunud intervjueeritavad ümberõpet. Samuti vajasid püsiva töökoha ja eriala säilitanud palgatöötajad muutustega kohanemiseks uusi oskusi ja teadmisi, mida asuti omandama peamiselt tööalase täiendusõppe kursustel. Vaid üks intervjueeritav oli osalenud tasemeõppes (Silvi, tabel 3), 2001. aastal omandas ta magistrikraadi. Täienduskoolitused olid ka kui eneseabivahendid, mis leevendasid küsitletute isikliku elu traumat: „Otsisin hästi aktiivselt lahendusi oma elu probleemidele" (Silvi).

Vabahariduse koolitustel osalemist ei seostatud siirdeaja algul tööalase arenguga, mistõttu ei kujunenud see koolitusliik kõige populaarsemaks, ent siirdeaja lõpul elukvaliteedi paranedes tekkis selle koolitusliigi vastu huvi: „Mis ma seal ikka käin, kõike on võimalik töö kõrvalt õppida” (Anna); „Ma olen savipotikesi käinud tegemas, ma tahtsin seda kedretööd proovida, seal on igasugused põnevad loengud" (Alice).

Intervjueeritavate meenutused võimaldavad kirjeldada täiskasvanuhariduse võimalusi ja arengusuundumusi siirdeaja eri etappidel. Radikaalsete majandusreformide ajal, 1990ndate algul pakuti peamiselt juhuslikult toimuvaid ja ebarahuldavalt korraldatud lühiajalisi koolitusi: „Alguses koolitused ei olnud ikka koolituste moodi" (Alice). Sellel segaduste ja koolitusturu kujunemise ajajärgul eelistasid intervjueeritavad peale kursustel osalemise omandada ka iseseisvalt uusi oskusi (informaalne õpe): „Siis ma hakkasin kibekiirelt ise õppima. Alguses sai otsitud pagan teab mis koha pealt ja kuskilt ei olnud midagi võtta" (Alice).

Üsna tunnuslik on see, et intensiivne tööelu sundis erialaseid lisateadmisi iseseisvalt hankima, mida võib seostada nõukogude haridussüsteemis omandatud õpioskuste ja -rutiiniga. Uue kultuurilise kapitali abil liituti siirdeaja muutuva tööturuga, mille üleminekuetapis vajati ka nõukogudeaegsete töötajate erialast hariduspagasit ja töökogemust. Seega tugev nõukogudeaegne vana kultuuriline kapital kujunes omamoodi radikaalsete muutuste riskide maandajaks: „Nendest [kõrgkoolis õpitud oskustest] oli väga palju kasu” (Toomas); „Me saime ikka kõva aluse” (Toivo). 
Reformidejärgsel stabiilsemal tehnoloogiliste uuenduste ajal 1990ndate teisel poolel korraldati koolitusi süsteemsemalt. Eurointegratsiooni perioodil (1999-2004) muutusid koolitused regulaarsemaks. Siirdeaja viimasel perioodil (2005-2008) toimis elukestva õppe keskkond juba riiklikult suunatud uue täiskasvanute hariduspoliitika strateegiate alusel, mida toetasid ELi projektid (Haridus- ja Teadusministeerium, 2005).

Koolitustel osalemise mõju ja tulemuslikkust võib kaudselt hinnata ka intervjueeritavate siirdeaja karjääriteede kujunemise kaudu. Elukestva õppe keskkond kui uus kultuurilise kapitali vorm aitas kaasa nõukogudeaegse sotsiaalse positsiooni säilitamisele või ümberkujundamisele. Intervjueeritavate siirdeaja töökarjäär kujunes tänu uuele kultuurilisele kapitalile stabiilseks ja mitmete puhul lausa edukaks (tabel 3).

Tabel 3. Intervjueeritavate töökohtade, ametite ja erialaga seotud muutused aastatel 1988-2011

\begin{tabular}{|c|c|c|c|c|c|c|c|}
\hline Nimi & $\begin{array}{l}\text { Eriala, amet } \\
1988-1991\end{array}$ & $\begin{array}{l}\text { Töö- } \\
\text { tus }\end{array}$ & $\begin{array}{l}\text { Eriala, amet } \\
2011\end{array}$ & $\begin{array}{l}\text { Elukutse } \\
\text { muutus }\end{array}$ & $\begin{array}{l}\text { Ette- } \\
\text { võtja }\end{array}$ & $\begin{array}{l}\text { Töö- } \\
\text { võtja }\end{array}$ & $\begin{array}{l}\text { Töökoha } \\
\text { staaž } \\
\text { aastates }\end{array}$ \\
\hline Toomas & $\begin{array}{l}\text { Vanemmeister, } \\
\text { konstruktor }\end{array}$ & & IT-ettevõtja & $\begin{array}{l}\text { Eriala- } \\
\text { lähedane }\end{array}$ & $x$ & & 20 \\
\hline Toivo & Ehitusinsener & & Ehitusõpetaja & $\begin{array}{l}\text { Eriala- } \\
\text { lähedane }\end{array}$ & & $x$ & 10 \\
\hline Tarmo & $\begin{array}{l}\text { Trükikoja } \\
\text { peainsener }\end{array}$ & & $\begin{array}{l}\text { Trükikoja } \\
\text { tegevjuht }\end{array}$ & Õpitud eriala & & $x$ & 34 \\
\hline Taimi & $\begin{array}{l}\text { Puidu- } \\
\text { tehnoloog }\end{array}$ & & $\begin{array}{l}\text { Puidu- } \\
\text { tehnoloog }\end{array}$ & Õpitud eriala & & $x$ & 20 \\
\hline Albert & $\begin{array}{l}\text { Sovhoosi } \\
\text { peazootehnik }\end{array}$ & & Talupidaja & $\begin{array}{l}\text { Eriala- } \\
\text { lähedane }\end{array}$ & $x$ & & 21 \\
\hline Alex & $\begin{array}{l}\text { Sovhoosi } \\
\text { peazootehnik }\end{array}$ & $x$ & Pottsepp & Uus eriala & $x$ & & 5 \\
\hline Alice & $\begin{array}{l}\text { Metsakasvatuse } \\
\text { vaneminsener }\end{array}$ & $x$ & $\begin{array}{l}\text { Keskkonna- } \\
\text { ametnik }\end{array}$ & $\begin{array}{l}\text { Eriala- } \\
\text { lähedane }\end{array}$ & & $x$ & 5 \\
\hline Anna & $\begin{array}{l}\text { Sovhoosi } \\
\text { zootehnik }\end{array}$ & $x$ & $\begin{array}{l}\text { Riigiametnik, } \\
\text { tippjuht }\end{array}$ & Uus eriala & & $x$ & 2 \\
\hline Siiri & $\begin{array}{l}\text { Vabakutseline } \\
\text { kunstnik }\end{array}$ & $x$ & ELi projektijuht & Uus eriala & $x$ & & 3 \\
\hline Salme & Ajalooõpetaja & & $\begin{array}{l}\text { Ajaloo, inglise } \\
\text { keele õpetaja }\end{array}$ & $\begin{array}{l}\text { Õpitud eri- } \\
\text { ala, uus eriala }\end{array}$ & & $x$ & 27 \\
\hline Silja & Arst & & Arst, tippjuht & Õpitud eriala & & $x$ & 31 \\
\hline Silvi & Klubitöötaja & & Koolitaja & Uus eriala & & $x$ & 8 \\
\hline
\end{tabular}


Karjääriteede järgi võib intervjueeritavad jagada kolme rühma. Esimesse, töökoha püsivuse poolest silma paistvasse rühma kuulus neli intervjueeritavat (Tarmo, Taimi, Salme, Silja), kes säilitasid kogu siirdeaja jooksul oma töökoha (töötamine samas asutuses) ja eriala. Kõik selle rühma esindajad on palgatöölised. Teine rühm (Toomas, Toivo, Albert, Alice) moodustus neist, kel siirdeajal töökoht muutus, kuid kes sälitasid erialalähedase töö ja ameti. Selles rühmas on nii palgatöötajaid (keskkonnaametnik ja ehitusõpetaja) kui ka ettevõtjaid (IT-ettevõtja ja talupidaja). Kolmas rühm (Alex, Anna, Siiri, Silvi) kujunes neist, keda siirdeaja algul tabas eriala ja töökoha kaotamise tõttu ka töötus. Nende ühistunnuseks on uus eriala, mis on omandatud juba siirdeaja jooksul. Selles rühmas on nii ettevõtjaid kui ka töövõtjaid, kogu rühma iseloomustab ka kõige lühem tööstaaž (tabel 3). Selle rühma karjääriteed on kõige enam seotud siirdeaja keskkonna muutustega.

Uurimistulemustest ilmneb, et kõik intervjueeritavad suutsid reformide ajal tööelus kiiresti kohaneda, milles oli erialastel täiendus- ja ümberõppe koolitustel täita tähtis osa. Vaid üks intervjueeritavatest (Taimi, tabel 3) ei osalenud ühelgi koolitusel, oma töökoha ja pikaajalise stabiilse staaži (20 aastat) säilitas ta iseseisvalt uute oskuste juhusliku hankimise kaudu: „Minusugust koolitab ostja, tuleb, nõuab, tahab, siis sa hakkadki ennast sellega kurssi viima, uurima, mis värk on, et niimoodi juhtumisi ennast koolitad nagu" (Taimi).

Kokkuvõtteks: uuring näitas, et siirdeaja karjääriteede edukus sõltus eelkõige tööalastel koolitustel kogutud uuest kultuurilisest kapitalist. Oluliseks kujunes nõukogudeaegne erialane kvalifikatsioon, mis aitas mitmel intervjueeritaval säilitada oma erialane töökoht. Kuidas suutis vaadeldav uuringurühm omandada siirdeaja baasoskusi (võõrkeel, arvuti) ja millisel määral mõjutasid need oskused konkurentsivõimet, vaatlen järgmises osas.

\section{Uute baasoskuste omandamine}

Siirdeaja baasoskused, st need pädevused, mis erialast olenemata võimaldasid tööelus edukamalt toime tulla, olid võõrkeel, arvutioskus ja sotsiaalne suhtlus (Märja, 2008; Vöörmann, Helemäe, Saar, \& Kazjulja, 2005). Tänapäeval peetakse peamisteks baasoskusteks tehnoloogilist kirjaoskust ehk probleemilahendusoskusi tehnoloogilistes keskkondades (Halapuu \& Valk, 2013). Siirdeaja algul 1990ndatel domineeris baasoskuste koolitustes elukestva õppe sotsiaalne dimensioon (Illeris, 2003; Jarvis, 2007; Quane, 2008) ehk sotsiaalse järeleaitamise suund (Aarelaid-Tart, 1999), mis väljendus nii kolmanda sektori vabahariduslike koolituste temaatikas kui ka erafirmade kursuste pakkumistes (Eesti Vabaharidusliit, 2003; Märja, 2008). 
Uuringus käsitlen siirdeaja baasoskustest arvutiõpet ja inglise keelt. Andmeid baasoskuste kohta sain elukestvas õppes osalemise lisaküsimuste abil, mille vastustest kodeerisin õppes osalemise viise ja intervjueeritavate hinnanguid oma oskustele. Viiteid baasoskustele ilmnes ka täiskasvanuhariduse koolitusliikide (tööalase täiendusõppe, vabahariduse) ja informaalses õppes osalemise analüüsikategooriate määratlemisel. Uurimistulemuste analüüsil selgusid baasoskustel põhinevate õppimisvõimaluste ja õpihoiakute kategooriad. Siinses tulemuste analüüsi osas on kesksel kohal need baasoskuste analüüsikategooriad, kus intervjueeritavad kirjeldavad oma õpihoiakuid, eesmärke ja vajadusi. Baasoskuste omandamise tulemuslikkust võib tõlgendada õppes osalemise, õppimisviiside, omandatud taseme ja erialaste kasutusvõimaluste järgi.

\section{Hinnangud baasoskustele}

Keeleoskuse puhul ei hinnanud ükski vastaja oma taset kõrgelt, hinnangud kõikusid puudulikust keskmiseni, domineerima jäi pigem nõrk tase. Oma oskusi kirjeldati järgmiselt: minimaalne sõnavara, rahuldav lugemisoskus, tavakasutaja suhtlusoskused. Enamikul oli säilinud kunagine keskkooliaegne passiivne inglise keele oskus, mis sisaldas minimaalselt erialaseid teadmisi. Võrreldes siirdeaja algusega keeletase oluliselt ei paranenud, sest keele praktiseerimise võimalused jäid tagasihoidlikuks.

Olen püüdnud hoida sellist taset, et ma jänni ei jääks ... Valdamiseks ei saa nimetada, aga hakkama saan kuidagimoodi, ega ma väga punnitanud ei ole. (Alex)

Lapsed on ju ja pereelu ja igasugused muud asjad ... Peab selleks palju aega olema ... Mäluga seotud õppimine on praegu raskem. Tegelikult on nii palju huvitavat teha, ikka panen asjad kuskile järjekorda. Mul on küll inglise keele õpik kogu aeg laua peal. (Silvi)

Ma olen töö juures küllaltki koormatud olnud. (Tarmo)

Võõrkeele nõrga taseme põhjuste lausungeid võib seostada vähese õpihuviga, mida mitmed vastajad püüdsid õigustada ealise eripäraga. Põhjustena toodi ka ajapuudust ja perega hõivatust. Eraettevõtete palgatöötajad nimetasid madala keeletaseme põhjuseks töökoormust ja tööandja vähest initsiatiivi.

Arvutioskuse puhul määratles enamik vastajaid ennast tavakasutajana. Omandatud taset hoiti tööks vajalike elementaarsete oskuste piires. Seevastu arvutioskuse taseme hinnangutes oldi enesekriitilisemad, sest võrreldes keeleõppega tajutakse digitaalse keskkonna muutusi vahetumalt. 
Arvestades seda, kuhu maani on tänapäeva infotehnoloogia tõusnud, siis ma ei ole täna kõva käpp. (Silvi)

Ma käisin huvi pärast [teises ettevõttes] vaatamas, seal on üks programmi juhtimisega pink, väga moodne, siis ma pidin tõdema, et mõned asjad on moodsamaks jõudnud. (Tarmo)

Üsna kriitilistest enesehinnangutest hoolimata võib siiski mitmete eriala uuendustega kursis olevate intervjueeritavate (Alice'i, Toomase, Alexi) taset hinnata siirdeaja oskuste kontekstis tavakasutajate omast kõrgemaks, sest nad olid õppinud kasutama ka tööga seotud programme ja omandanud spetsiifilisemaid arvutioskusi (AutoCAD, programmeerimine, raamatupidamisprogramm). Intervjueeritavate enesehinnangut tuleks vaadelda tänapäeva IKT arengu taustal. Just tehniliste erialade esindajad kippusid oma taset võrdlema peamiselt uuemate võimaluste kontekstis. Põhjused, miks intervjueeritavate baasoskused jäid tagasihoidlikuks, ilmnevad õppijate õpihoiakutest ja õppimisviiside analüüsikategooriatest.

\section{Õpihoiakud, eesmärgid ja vajadused}

Õpihuvi käsitlevates uurimustes rõhutatakse õppimisest arusaamise aspekte, mis on seotud inimese teadlikkuse, ootuste ja õpivalmidusega (Illeris, 2007; Jõgi, 2006). Õpihoiakute analüüsikategooriates ilmnevad nii sisemised kui ka välised tegurid. Sisemised tegurid on seotud isiksusetüübiga, avaldudes selles, kas isik on õppimiseks sisemiselt valmis või mitte. Väliseid tegureid mõjutavad õppes osalemise võimalused ja õppimiskeskkond.

Inglise keel. Intervjueeritavate vastuste põhjal võib sedastada, et võõrkeeleoskuse vajadustele jätsid oma pitseri nõukogudeaegsed hoiakud ja tollased napid keele praktiseerimise võimalused. Siin ilmnevad nii sisemised (isiksusetüüp) kui ka välised tegurid. Teatavasti oli nõukogudeaegne erialakirjandus valdavalt venekeelne, vajadus inglise keele oskuse järele hakkas suurenema alles siirdeaja eurointegratsiooni etapil, st siirdeaja lõpul.

Vene ajal oli keeltega nagu oli. Nagunii välja ei saa, ei ole mõtet õppida. See on meie põlvkonna jama. Inglise keelest võin ma ainult unistada, et saaks kasvõi saksa keele suhtlustasandil meelde tuletatud. (Toivo)

Intervjuu tekste kodeerides selgus, et siirdeaja algul ei tajutud vajadust võõrkeeleoskuse järele, mistõttu domineeris keeleõppe eesmärkide lausungites 
pigem isikliku arengu tegur, mitte soov parandada tööalast konkurentsivõimet. See näitab, et inglise keele oskus polnud siirdeajal tööhõives püsimise seisukohalt veel esmatähtis. Ühelt poolt võis see tekitada kindlust, teiselt poolt ebakindlust, mis omakorda vähendas tööga seotud mobiilsust ja julgust muuta oma karjääri. Mitu vastajat nimetas stabiilses hõives püsimise tegurina ka erialast kompetentsi ja teiste võõrkeelte (vene ja saksa keele) oskust, mis kompenseerisid mõnes situatsioonis vähest inglise keele oskust.

Ma olen selle kahe keelega (vene, saksa) suutnud säilitada seda kohta, mida teised on suutnud hoida inglise keelega. Ma olen ikkagi võrdne nendega. (Tarmo)

Vajadus mõne võõrkeele oskuse järele selgus konkreetsetes töösituatsioonides ja erialaste oskuste hankimisel.

No ma olen vaadanud teine kord, et internetis ... inglise keeles ... leiaks palju rohkem asju [erialaseid teadmisi], aga jääb lihtsalt keelelise arusaamise taha. (Alex)

Kui siin hätta jäime, siis tellisime isegi endale töö juurde ka [kursusi]. (Toomas)

Inglise keel on see, mida mul on erialaselt vaja läinud. (Silvi)

Keelekursuste kõrge hind ei kajastunud vastustes kordagi mitteosalemise põhjusena. Valmisolek ise oma keeleõppesse investeerida oli olemas mitmel vastajal. Erialase keeleoskuse vajadusest hoolimata puudus vastajatel siiski piisav motivatsioon parandada oma oskusi.

Arvutiõpe. Võrreldes vajadusega inglise keele oskuse järele ja sellest tulenevate hoiakutega võib täheldada, et intervjueeritavad tundsid suuremat huvi arvutiõppes osalemise vastu, eriti siirdeaja algul. Siirdeajal alguse saanud infoühiskonna tehnoloogilised võimalused tõid muutuste diskursusesse tuntavamaid uuenduste tuuli. Kiiresti arenev IKT valdkond eeldas arvuti pidevat kasutamist, mis võis olla intervjueeritavate õpimotivatsiooni üheks stimuleerijaks. Intervjueeritavate aktiivse arvutiõppe algusaeg jäi valdavalt 1990ndate algusesse. Kursustele satuti asutuste kaudu või ka omal initsiatiivil. Vaid kaks intervjueeritavat (Albert, Taimi) polnud kordagi arvutiõppes osalenud. Mitmed vastajad väitsid aga, et siirdeaja alguse arvutiõppe oskused ununesid arvutite puudusel peagi, mis sundis arvutioskusi edasi arendama iseseisvalt või töö juures infotehnoloogi abil. Arvutioskusi arendati nii töiseks kasutamiseks kui ka oma tarbeks. 
Et kaasaegsemate asjadega kaasa minna, see tuleb ikka enda seest. IT-alane teadmine tuli aastal 2001, kui ma läksin magistriõppesse. (Silvi)

Me oleme ise nii palju huvi tundnud selle [arvutiõppe] vastu. (Alice) Mul peab see olema kogu aeg kasutada [tööalaselt, koolitunnis], siis ma arenen edasi. (Salme)

Kui meil tuli see haigla infosüsteem, selle jaoks oli eraldi koolitust vaja. (Silja)

Õpihoiakutes ja -eesmärkides võib märgata nii sisemist valmisolekut (Silvi, Alice) kui ka välist survet (Salme, Silja). Sellist entusiastlikku arvutiõppeks valmisolekut, nagu see ilmnes võõrkeele õppimise kirjeldustes, ei avaldanud ükski intervjueeritav. Arvutiõppe puhul oli olulisem erialase arengu perspektiiv. Tehnilistel erialadel töötavad vastajad soovisid, et neil oleksid paremad erialaspetsiifilised arvutioskused. Samas kurdeti tööandjate ükskõiksuse üle.

Tööandjapoolne surve peaks olema, et kuule, nüüd on sellisele koolitusele vaja minna. Võib-olla oleks ma pidanud ise tööandja käest rohkem nõudma ... Ilmselt enda laiskus ka, et kindlasti on võimalik seda ise õppida. (Taimi)

Lõpetasin [arvutikursuse], sain paberi, aga seda keegi töö juures ei küsinud. Lihtsalt see oli enda tarvis, et ma hakkaks seal sees paremini orienteeruma. (Tarmo)

Seega võib üldistades öelda, et intervjueeritavate siirdeaja baasoskuste õpihoiakud olid eelkõige kontekstuaalsed, seotud nii isikliku arengu kui ka töökeskkonnaga ning need sõltusid peaasjalikult konkreetsetest eesmärkidest ja vajadustest. Täiskasvanute õpihoiakud olenevad ka positiivsetest ja negatiivsetest õpikogemustest ning tööandjate ja lähedaste suhtumisest omandatud oskustesse.

\section{Baasoskuste omandamise viisid}

Intervjueeritavate siirdeaja baasoskuste omandamise viiside narratiivides kajastusid eelkõige õpikeskkonnad ja -võimalused. Enamik vastajaid oli osalenud algajate inglise keele kursusel. Aja jooksul täiendati ennast iseseisvalt mõne arvutiprogrammi abil, internetis, koolis käivate laste kõrvalt nende õpikuid lugedes. Arvutioskuste omandamise kogemused meenutasid võõrkeeleõppe omi: algul saavutati teatud tase, kuid saadud oskusi täiendati juhuslikult ja vajaduse korral kõrvalise abiga. Mõlema oskuse puhul kasutati 
tööalaseks enesetäienduseks ka internetti, mis kujunes intervjueeritavatele üheks informaalse õppe keskkonnaks. Internet asendas peamiselt tehniliste erialade töövahendeid, tavaliselt otsiti erialast infot, sest erialaseks tööks vajalikud tehnilised vahendid (eriprogrammid) puudusid.

Pooljuhuslikult uut infot otsides. Mul ei olnud väga asja sinna kodulehele, aga noo ... sain jälle natukene targemaks. (Taimi)

Kui mul on midagi tarvis ... tööasjus just, siis ma lähen ja otsin seda sealt [internetist]. (Tarmo)

Veebikeskkond (e-õpe, internet) ei kujunenud intervjueeritavate meenutustes kõige populaarsemaks õppimisviisiks. Veebikeskkonda kasutati juhuslikult, peamiselt uue info otsimiseks. Vastajate arvates ei ole nad interneti kaudu oma arvutioskusi edasi arendanud. See hinnang on pigem implitsiitne, vastajail on kiiresti muutunud oludes objektiivseid hinnanguid raske anda, sest praeguseks on piir igapäevase õppimise ja arvuti kasutamise vahel kadumas. Virtuaalse keskkonna arengu olulisust ei suutnud siirdeaja alguses ette näha ega hinnata ei töövõtjad (intervjueeritavad) ega tööandjad. Ilmselt ei tajunud mõlemad pooled veel globaalse tehnoloogilise siirde ulatust ja sügavust.

Kokkuvõtvalt võib öelda, et intervjueeritavad pidasid oma baasoskusi suhteliselt kesiseks ja ei olnud eriti aktiivsed nende täiendamisel. Siirdeaja alguse aktiivsemad hoiakud ei leidnud väljundit, sest puudusid võimalused omandatud oskusi rakendada. Baasoskuste omandamise väheaktiivsed õpihoiakud olid tingitud ka vähesest tööalasest motivatsioonist ja nõrgast seosest hõives püsimisega. Baasoskuste tase ei olnud erialase kvalifikatsiooniga piisavalt seotud ning nende arendamist ei soosinud ka tööandjad ega töökeskkond.

Kindlasti oli baasoskuste arengu tagasihoidlikes tulemustes oma osa ka elukaarest johtuval teguril. Siirdeaja radikaalsed muutused ei loonud soodsat keskkonda aktiivses tööeas intervjueeritavatele, kellel oli noor pere ja keda ohustas karjääri katkemine, mistõttu nad ei saanud osaleda kõikides uuendustes korraga.

\section{Elukestev õpe ja vananemine}

Seoses kiiresti areneva digiajastuga võib lähiajal saabuda tööturul siirdeaja algusega sarnane muutuste periood, mis nõuab töötajate keskealiselt ja vanemalt põlvkonnalt taas valmisolekut uuendada oma kultuurilist kapitali (Kalkun \& Kalvet, 2002; Perez, 2002). Siinses osas analüüsitakse intervjueeri- 
tavate hoiakuid (orientatsioone) kultuurilise kapitali uuendamiseks tulevikus. Uuringu andmed kujunesid kahe küsimuse vastuste analüüsi põhjal:

- Kas Te oleksite valmis minema tasemeõppesse (kõrgkooli või kutsekooli) oppima uut eriala?

- Millisel määral võiks tulevane enesetäiendamine mõjutada toimetulekut vanemas eas?

Nende küsimuste esitus sundis intervjueeritavaid hindama oma senist õpivalmidust ja sellega seotud tulevikukavatsusi. Mõlema küsimuse vastustes tekkis seoses siirdeaja kultuurilise kapitali uuendamise kavatsuste ja õpivalmidusega eristus- ja võrdlusvõimalus.

Andmeanalüüsi tulemusel jagunesid intervjueeritavad kolme õppijatüübi kategooriasse (A, B ja C), mille tunnused eristusid kultuurilise kapitali uuendamiseks valmisoleku ning õppimise ja vanadusega toimetuleku seoste teadvustamise põhjal (tabel 4).

Tabel 4. Intervjueeritavate kategoriseerimine elukestvas õppes osalemise tüübi alusel

\begin{tabular}{|c|c|c|}
\hline Tüübid & Tüübi tunnused & Intervjueeritav \\
\hline Tüüp A & $\begin{array}{l}\text { 1. Tasemeõppeks valmisolek: siirdeaja kultuurilise kapitali } \\
\text { uuendamine } \\
\text { 2. Teadvustab enesetäiendamise tähtsust vanemas eas, } \\
\text { koolituse vorm/liik täpsemalt veel kindlaks määramata }\end{array}$ & $\begin{array}{l}\text { Albert, Silja, Silvi, } \\
\text { Toomas, Alex, } \\
\text { Siiri }\end{array}$ \\
\hline Tüüp B & $\begin{array}{l}\text { 1. Siirdeaja kapitali uuendamine tulevast tasemeõpet ei hõl- } \\
\text { ma, tulevikku ei seostata veel kindlalt uute õpingutega } \\
\text { 2. Vananemise teadvustamine on pigem traditsiooniline, } \\
\text { konservatiivne, ollakse vähem orienteeritud teadlikule } \\
\text { õppimisele, enesekindlus saavutatakse tänu varem oman- } \\
\text { datud kvalifikatsioonile }\end{array}$ & $\begin{array}{l}\text { Anna, Salme, } \\
\text { Toivo, Alice }\end{array}$ \\
\hline Tüüp C & $\begin{array}{l}\text { 1. Siirdeaja kapitali uuendamine tulevast tasemeõpet ei } \\
\text { hõlma, uute õpingutega kaasnevad hirmud, kahtlused } \\
\text { 2. Enesetäiendamise tähtsus vanemas eas seotakse vanade } \\
\text { erialateadmiste taastamise või värskendamisega }\end{array}$ & Taimi, Tarmo \\
\hline
\end{tabular}

Õppijatüüpide tunnuseid kokkuvõtvast tabelist 4 ilmnevad seosed õpihoiakute ja vananemisega kaasneva õppimisvajaduse teadvustamise vahel. Aktiivsema õpihoiakuga elukestvas õppes osaleja tüüp (A) väärtustab ka vanemas eas enesetäiendamist. Passiivsema õpivalmidusega tüüpide $(B, C)$ kultuurilise kapitali uuendamist takistavad vana kapitaliga kaasnev inertsus ja ebakindlus. 
Ettevõtliku õppijatüübi (A) vastustes domineerisid tasemeõppeks valmisoleku hoiakud: „ma olen mõelnud” (Silja, Silvi); „ma võiks ju minna doktorisse” (Siiri); „ma läheks majandust õppima” (Toomas); „ma arvan, et õigusteaduskond” (Albert); „selles mõttes ma olen avatud” (Alex).

Alalhoidlik õppijatüüp (B) eristus eelnevast siirdeajal kogutud kapitali status quo soovi poolest. Selle tüübi vastused tasemeõppeks valmisoleku kohta olid kahtlevad ning ei sisaldanud osutust tulevasele tasemeõppele kui võimalusele uuendada oma siirdeaja kapitali: „koormus on ikkagi väga suur” (Anna); , aga kõik käib raha eest, see on see, mida mul praegu ei ole” (Alice); „mul oma töökoht on siin, ma tunnen end hästi ja mugavalt ... Ju ma kardan selliseid kardinaalseid muutusi” (Salme); „... see ohverdaks tööd” (Toivo).

Mitteosaleja tüüp (C) ei suutnud leida endas valmisolekut midagi uut õppida. Selle tüübi vastustest ilmnevad välised tegurid - pereväärtused ja stabiilne töökoht - on küll positiivse kaaluga, kuid samas peegeldavad need ka aktiivset õpivalmidust mittetoetavat hoiakut ja mõningast ebakindlust tuleviku suhtes.

Kunagi varem sai mõeldud ..., et teist ülikooliharidust saada ... Ma ei ole leidnud jõudu ja tahtmist, ... pereväärtused on ka olnud siiamaani. (Tarmo)

Ma olen nii hakkama saanud. Laveerides kuskil seal noatera peal, ... mul ei käi seda klõpsu, ... võib-olla mugavdunud olen ma juba mingil määral. (Taimi)

Õppijatüüpide siirdeaja kapitalipagasi hinnangutes ja selle uuendamise võimalustes ning uuendamist takistavates põhjustes ilmnesid tüüpide erisused üsna selgelt. Tüüp A nimetas vastustes juba konkreetseid ümberõppe valdkondi. Selgus, et selle tüübi esindajad olid ka varem uuele erialaõppele mõelnud, seega valmisolek kardinaalselt oma karjääri ja kultuurilist kapitali muuta oli ilmne. Tüüp B põhjendas oma ettevaatlikkust pigem sotsiaalsete garantiide puudumise või lakkamise ohuga, esikohal oli praegu veel turvatunnet pakkuv töökarjäär. Tüübi $\mathrm{C}$ vastustes peegeldus jõuetus muudatusi teha ja leppimine oma ebakindla olukorraga.

Kõikide õppijatüüpide (A, B, C) seisukohad, mis puudutasid enesetäiendamise mõju vananemisega toimetulekule, olid samuti erinevad. Oma vastustes oldi küll ebamäärasemad, kuid erinevused joonistusid siiski välja.

Ettevõtliku õppijatüübi (A) esindajad seostavad vananemist õppimisega, pidades silmas nii varasemaid oskusi ja kogemusi kui ka otsest enesearendamist. 
Nüüd võiks vist õppima hakata ..., kuidas tervist säästa ja ... [naerab] kuidas ratastooliga hästi ringi liikuda. (Toomas)

Mina mõtlen ikka, et ma püüan lõpuni vastu pidada siin [talus], ... teha ikka midagi, mida oskad. (Albert)

Mida rohkem ma õpin, seda rohkem läheb aega unustamisega. (Silja)

Siiski ei teadvusta see tüüp õppimise ja vananemise seost veel väga selgelt, pigem on see kauge tulevik, milles óppimisel on küll oma osa, kuid see seos on veel mõtestamata: piirdutakse seniste kogemustega ja siirdeaja lõpu elukestva õppe mainekujundusliku käibefraasiga „väärikas vananemine”. Samas ei tunta hirmu, pigem julgetakse vananemise suhtes olla humoorikalt skeptilised.

Alalhoidliku õppijatüübi (B) vananemise teadvustamine on pigem traditsiooniliselt konservatiivne (padjaklubi, talu kohendamine, lapselapsed), vähem orienteeritud teadlikule õppimisele.

Kui ma oleks juba pensionil ..., siis ma tahan, et oleks lihtsalt midagi ... Teatud nädala kuupäeval saame kokku ja padjaklubi. (Salme)

... aga mis siin koolitada, üks minu hobi on oma kätega midagi teha. Mul on see väljund olemas, isa talu, ei jõua kõike ära teha, mis plaanid on. (Toivo)

Kuna õppijana on ennast harjutud määratlema eelkõige konkreetsete tööoskuste omandamise abil, seostatakse vananemist ja õppeprotsessi veel üldsõnaliselt ja praktilise toimetulekuga. Selle tüübi puhul domineerivad pigem passiivsed hoiakud.

Mitteosaleja tüüp (C) ei seosta vanadusega toimetulekut uute õppimisvaldkondadega, pigem soovitakse vanemas eas taastada oma kvalifikatsioon, et vähendada senise põhierialaga seotud ebakindlust, sest vana on turvalisem kui uus. Võib arvata, et kunagine tugev siirdeaja stardiressurss - nõukogudeaegne tehniline kõrgharidus (vana kultuuriline kapital) - kujunes sellele tüübile nii veduriks kui ka piduriks ehk arengulõksuks, sest tekitas pikaajalist toimetulekuillusiooni, soodustades liigset enesekindlust ja pärssides sel moel erialaoskuste pidevat täiendamist. Nii ei tekkinud tihedaid elukestva õppe võrgustikke ja uusi kontakte, mistõttu satuti omamoodi elukestva õppe isolatsiooni. Seetõttu on sellel tüübil tekkinud madal enesehinnang, mis väljendub erialase toimetulekuga seotud kartustes: „kas enam veab välja”, „rong on läinud”, „liiga kiiresti lähevad asjad eest ära”. Vana kapitaliressurss, mis toimis kogu siirdeajal, on hakanud uute muutuste kontekstis 
oma väärtust kaotama, ka 2008. aastal alanud majanduskriisiga kaasnenud riskid võisid soodustada selle tüübi ebakindlust.

Mingi huvi on säilinud veel oma põhieriala vastu ..., aga ma olen aastatega selle kvalifikatsiooni kaotanud, ... kui ma saaksin selle taastada, sest vahepeal on tehnoloogia, masinad läinud edasi. (Tarmo)

Inseneri mõtte poole pealt oli ta ikka väga kõva haridus. ... ühte pidi ihaldaks uut ja teistpidi ei taha. (Taimi)

Õppijatüüpide eristamisel selgus, et ka siirdeajal omandatud kultuuriline kapital võib kujutada endast arengulõksu, kui seda ei uuendata pidevalt. Nii näiteks ei seosta alalhoidlik õppijatüüp (B), kes oli siirdeperioodil edukas kohaneja - osales aktiivselt elukestvas õppes -, oma tulevikku enam kiirete kapitalimuutuste vajadusega. Toetumine olemasolevale ja liigne enesekindlus oma senise taseme suhtes ei soodusta uute muutustega seotud ohtude teadvustamist, mistõttu võivad alalhoidliku õppijatüübi (B) siirdeaja oskused kujuneda arengulõksuks, nagu ka mitteosaleja tüübi (C) vanad oskused.

Õppijatüüpide B ja C kapitali uuendamise piduriks võib pidada ka sotsiaalset aspekti: töökeskkonda, tööd ja õppimisvõimalusi. Mitteosaleja tüübi (C) esindajad olid palgatöötajad eraettevõtetes, kus ei panustatud küllaldaselt töötajate erialase kvalifikatsiooni parandamisse. Kõik alalhoidlikku õppijatüüpi (B) kuulunud vastajad töötasid eelarvelistes asutustes (kohaliku omavalitsuse ametnik, riigiasutuse tippametnik, üldharidus- ja kutsekooli õpetaja), kus soodustati küll erialast enesetäiendamist, kuid kus võis puududa ametisisene konkurents. Stabiilsusesoov võis olla seotud ka äsjase majanduskriisi kogemustega - ei julgeta enam riskida.

Valmisolekut tulevasteks muutusteks ja katsumusteks esindas ettevõtlik õppijatüüp (A), kes tunnetab vajadust igasuguse õppimise järele, sh valmisolekut uuendada senist kapitali. Tal on tekkinud koolitusrutiin, -vajadus, -sõltuvus: „Kui aasta läheb mööda ja ma ei ole kuskil koolitusel käinud, siis ma hakkan sügelema ..., ma pean minema" (Silvi). Kõik selle õppijatüübi esindajad töötasid erafirmades, avalik-õiguslikes või sihtasutustes. Kuna eraettevõtlusega sarnane konkurents oli siin tuntavam kui eelmiste õppijatüüpide töökeskkondades, võib ettevõtliku õppijatüübi hinnangutes ja käitumismustrites märgata ka klassikalisi bourdieulikke (majandusliku ja kultuurilise) kapitali konverteerimise ilminguid. See õppijatüüp kasutas muutuste ajal omandatud teadmisi ja oskusi kõige enam ka reaalselt (uus kultuuriline kapital), sidudes neid oskuslikult oma majanduskapitaliga. 


\section{Arutelu}

Uurimuses analüüsisin nõukogudeaegse kõrgharidusega vanemaealise põlvkonna elukestvas õppes osalemist siirdeajal ja sellega kaasnenud osalejate sotsiaalse staatuse muutusi. Sotsiaalse positsiooni hõivamist radikaalsete muutuste perioodil käsitlesin eelkõige Bourdieu $(1984,2003)$ kultuurilise kapitali teooriale tuginedes, mille järgi võib erinevate kapitaliliikide (sotsiaalse, kultuurilise ja majandusliku kapitali) osakaal mõjutada indiviidide eristumist sotsiaalses ruumis. Bourdieu arvates saab sotsiaalse positsiooni hõivamisel vähest majanduskapitali kompenseerida ka kultuurilise kapitali arvelt. Nõukogude aja kontekstis on mitmed eesti uurijad (Helemäe et al., 2000; Titma, 2002) jõudnud sarnaste tulemusteni: nõukogude ühiskonnas, kus majanduskapitali osa sotsiaalse staatuse eristumisel oli minimaalne, kujunesid kultuurilise kapitali taastootmise strateegiad olulisemaks. Ka Beckeri (1975) inimkapitali teooria lähtub teatud määral sellest printsiibist. 1990ndate globaliseerumisprotsessi ja infoühiskonnaga kaasnenud uued hariduse ja töömaailma vahelised seosed seavad need modernistliku paradigma teooriad ja uurimused uude valgusse. Kultuurilise kapitali olemus muutub aja jooksul, seda ei saa vaadelda enam pelgalt formaalhariduse kontekstis.

Kultuurilise kapitali uuendamise analüüsi põhjal võib järeldada, et intervjueeritavad ei suutnud realiseerida kõiki muutunud kultuurilise kapitali võimalusi. Kultuurilise kapitali uuendamisel jäädi liialt ühekülgseks: uuendada suudeti vaid traditsioonilist kultuurilist kapitali, mis on seotud eelkõige modernistliku industriaalse töömaailma ja hariduse aspektidega. Siia lisanduvad ka mitmed muud siirdeajaga seonduvad põhjused. Muutuste diskursuse kõrval said määravaks ka katkestuse diskursuse aspektid: vanade kapitaliliikide inertsus, lisapinge põlvkondliku elukaare trajektoorile ja neoliberaalsete haridusstrateegiatega kohanemise raskused. Katkestuse diskursusest hoolimata säilisid indiviidi tasandil ka siirde-eelsed normid ja tavad, sest nende väärtus makrotasandi kiirete muutuste käigus ei kahanenud samaväärse tempoga. Seega kujunes uue kapitali (majandusliku ja kultuurilise kapitali) kogumise protsess ambivalentseks. Siirdeaja majandusja kultuuriväljal (Bourdieu, 1984) eksisteerisid kõrvuti nii uus kui ka vana kapital, millega põimusid infoühiskonna tehnoloogilise siirdega kaasnevad sotsiaalne, majanduslik ja kultuuriline kapital. Klassikalised bourdieulikud väljasisesed hierarhiad ja ressursside süsteem muutus varasemast mitmekihilisemaks.

Mitmekihilisemaks muutusid ka kapitali uuendamise vajadused ja eesmärgid, mida intervjueeritavad ei suutnud täiel määral tajuda ega realiseerida. Uuendada suudeti eelkõige konkreetse erialaga seonduvaid 
oskusi, kuid siirdeaja tehnoloogiliste ja sotsiaalsete muutuste baasoskusi omandati tagasihoidlikumalt, sest majanduse kiiretest struktuurimuutustest hoolimata ei muutunud radikaalselt uute oskuste omandamise tehnilised võimalused. Baasoskuste omandamise eesmärgid ei sisaldanud ka tööoskuste omandamisega sarnast tähenduslikkust ja väärtuste agendat, seda oskust ei seostatud veel hõives püsimisega. Üheks baasoskuste omandamise madala taseme põhjuseks võib pidada ka 1990ndate Eesti täiskasvanuhariduse poliitikat, milles baasoskuste omandamine võrdsustati huviharidusega (Eesti Vabaharidusliit, 2003). Sel viisil loodi baasoskuste tähendusväljas esmalt sotsiaalse eneseabi kuvand (Aarelaid-Tart, 1999; Illeris, 2003).

Siirdeaja kultuurilise kapitali ebaühtlase arengu sotsiaalse tegurina võib nimetada ka põlvkondlikku faktorit. Nõukogudeaegse stabiilse tööeluga harjunud nooremate tööealiste põlvkonda koormas peale alanud pereelu ka töökarjääri katkemise oht, töötus ja muud toimetulekuprobleemid. Need tegurid ei võimaldanud kohe aktiivselt haakuda 1990ndate „innovaatiliste impulssidega" (Aarelaid-Tart, 1999).

Kultuurilise kapitali arendamise ebaühtlus ilmnes kolme õppijatüübi õpirefleksioonides, milles analüüsiti, kuivõrd teadvustavad intervjueeritavad siirdeajal kogutud kapitali väärtust tuleviku seisukohalt. Õpirefleksioonides võivad peegelduda ka erinevad isiksusetüübiga seotud refleksiooniaspektid: avatud isiksusetüüp soodustab kohanemist ja suletud isiksusetüüp halvendab toimetulekut (Arro, 2014). Siinses uurimuses selgitati pigem väliseid tegureid, mis võisid küll mõjutada õppija sisemisi hoiakuid, kuid need olid seotud eelkõige instrumentaalsete kapitali uuendamise protsessidega.

Õppijatüüpide analüüsi käigus selgus, et tugev kapital võib muutuda hoopis arengulõksuks, kui seda ei uuendata järjepidevalt. Siirdeaja alguse tõhus stardikapital - nõukogudeaegne kõrgharidus, mis oma universaalsete erialaste oskuste ja teadmistega aitas mõningal määral leevendada katkestuse diskursust -, kujunes minimaalse elukestva õppe pagasiga õppijatüübile arengulõksuks. Vana kapitaliressurss tekitas turvalise tööalase toimetuleku illusiooni, mis muutus kapitali uuendamisel piduriks. Sellesse lõksu langesid vähese elukestva õppe kogemuse, kuid pikaajalise tööstaažiga eraettevõtete palgatöötajad. Näiteks ei osalenud üks intervjueeritav kogu siirdeaja jooksul ühelgi täiendusõppe koolitusel. Oma stabiilse eriala tööstaaži suutis ta säilitada samas asutuses alates 1990. aastast. Tekib küsimus, kuidas õnnestus sellel töötajal ilma erioskusi uuendamata nii pikalt vastu pidada. Intervjuu toimumise ajaks oli tema oskuste ja teadmiste pagas juba kahanemas, mis avaldus erialases ebakindluses ja töökoha kaotamise hirmus. Samas puudus tal ka valmisolek uuendada oma oskusi, sest ta polnud teadlik elukestva õppe võimalustest. 
Sügavad õpihoiakud nõuavad õppija enda pingutust, seevastu pindmise õpirefleksiooni korral ei teadvustata õppimisvõimaluste ja -kogemuste väärtust piisavalt (Jõgi, 2006; Pilli, Sammul, Post, Aasjõe, \& Kruusamäe, 2013). Kapitali uuendamise protsessis aktiivsemalt osalenud eelarveliste asutuste töötajate õpirefleksioonides ilmnesid seoses tulevikuplaanidega juba passiivsemad hoiakud, mis toidavad tulevast arengulõksu. Eelarveliste asutuste töötajate kapitali uuendamist võisid pidurdada ka minimaalne asutusesisene konkurents ja formaalsed kvalifikatsiooninõuded. Uus siirdeaja kultuuriline kapital, mida järjepidevalt ei uuendata, võib lähiajal kujuneda isegi ohtlikumaks arengulõksuks, sest kiiretele muutustele kohandatud täiskasvanute täiendus- ja ümberõppe koolituste õpiväljundid ei sisalda enam pikaajaliseks kasutamiseks mõeldud oskusi ja teadmisi.

Kolmanda õppijatüübi järjepidevat kultuurilise kapitali uuendamise initsiatiivi hoidis ülal ettevõtlusele omane pinev konkurentsikeskkond, kus domineerisid juba siirdekultuuri edule orienteeritud väärtused (Kalmus \& Vihalemm, 2004; Kennedy, 2002). Tänu sellele suutis ettevõtlik õppijatüüp kõige enam kasutada bourdieulikku majandusvälja kapitali (Bourdieu, 1984).

Nagu selgus PIAAC uuringust, on Eesti keskealiste põlvkonnale iseloomulik suhteliselt vähene aktiivsus oma kultuurilise kapitali uuendamisel. Samal ajal eeldab digiajastu juba teisel tasemel kultuurilist kapitali, mille uuendamise käigus võivad siirdeaja nõrgad baasoskused kujuneda tugevaks arengubarjääriks (Halapuu \& Valk, 2013). Ka digiajastu kapital võib hakata toimima klassikalise bourdieuliku väljateooria põhimõttel, kus erinevate kapitaliliikide vahelise konkurentsi käigus otsustatakse nende vahetuskursi reaalne väärtus (Bourdieu, 1984, 2003).

Uurimuse piirangutena tulemuste üldistamisel võib nimetada järgmisi aspekte. Esiteks, võimalusi uuendada kultuurilist kapitali siirdeajal analüüsiti vaid 12 intervjuu najal, mistõttu ei saa tulemusi laiendada üldkogumile. Teiseks, uurimuses ei käsitletud andragoogilise aspekti mõju täiskasvanute õpikäsitustele (Jõgi, 2006) ja õppimist kui kogemuste transformeerimise protsessi (Jarvis, 2011), mis võib mingil määral kahandada õppijatüüpide analüüsi tulemuslikkust. Kolmandaks, juurdepääsu intervjueeritavate elukestvas õppes osalemisele võisid mõjutada ka uurimuses käsitlemata sotsiaalse kapitali aspektid (vanad ja uued võrgustikud, vt Putnam, 2008) ja demograafilised andmed (elukoht, sissetulek). 


\section{Järeldused}

- Intervjueeritavate nõukogudeaegse sotsiaalse positsiooni säilitamisel või ümberkujundamisel tugineti olulisel määral uuele kultuurilisele kapitalile, milleks kujunes siirdeaja elukestva õppe keskkond: tööalased täiendus- ja ümberõppe kursused.

- Tööhõives püsimise oluline tegur oli ka vana kultuuriline kapital. Nõukogudeaegne erialane kvalifikatsioon toimis tõhusalt neis valdkondades, kus majanduse struktuursed ümberkorraldused olid tagasihoidlikumad (sotsiaal- ja humanitaarvaldkonnas ning tehnilises valdkonnas).

- Siirdeaja baasoskuste omandamine ei kujunenud prioriteediks, sest karjääriteede edukus sõltus eelkõige tööalastel koolitustel kogutud uuest kultuurilisest kapitalist. Baasoskuse arendamist ei soodustanud ka tööandjad ja siirdeaja elukestva õppe poliitika.

- Siirdeaja mitmekihilise kultuurilise kapitali (tööalaste ja baasoskuste) tulemuslik konverteerimine majanduskapitaliks sõltus konkurentsikeskkonnast ja õppijatüübist.

- Passiivsete õpihoiakutega õppijad ei tajunud kapitali pideva uuendamise vajalikkust, mistõttu nende eelneval eluperioodil kogutud kapital vananes ja sellest kujunes arengulõks ehk illusioon oma kogutud kapitali jätkuvast tootlikkusest.

- Aktiivsed õpihoiakud soodustavad vananemisega kaasneva õppimise teadvustamist.

\section{Kasutatud kirjandus}

Aarelaid-Tart, A. (1999). Eesti rahvakultuur postmodernismi ajastul. R. Vettik (toim.), Eesti inimarengu aruanne 1999 (lk 92-97). Külastatud aadressil http://lin2.tlu.ee/ teap/nhdr/1999/EIA99est.pdf.

Antikainen, A. (1996). Living in a learning society: Life-histories, identities, and education. London: Falmer Press.

Arro, G. (2014). Eneserefleksiooni seosed sotsiaalse toimetulekuga ühe- ja mitmekeelsete õpilaste hulgas. Eesti Haridusteaduste Ajakiri, 2(1), 162-185. http://dx.doi.org/10.12697/eha.2014.2.1.07

Becker, G. S. (1975). Human capital: A theoretical and empirical analysis, with special reference to education. Chicago, London: The University of Chicago Press.

Bélanger, P., \& Federighi, P. (2000). Unlocking people's creative forces: A transnational study of adult learning policies (1st ed.). Hamburg: UNESCO Institute for Education. Retrieved from http://www.unesco.org/education/uie/pdf/PaulEng.pdf.

Bell, D. (1999). The coming of post-industrial society: A venture in social forecasting. New York: Basic Books. 
Bourdieu, P. (1984). Distinction: A social critique of the judgement of taste. Cambridge, MA: Harvard University Press.

Bourdieu, P. (2003). Praktilised põhjused. Teoteooriast. Tallinn: Tänapäev.

Castells, M. (2000). The rise of the network society (2nd ed.). Oxford, Massachussets: Blackwell.

Centeno, A. (2011). Lifelong learning: A policy concept with a long past but a short history. International Journal of Lifelong Education, 30(2), 133-150.

http://dx.doi.org/10.1080/02601370.2010.547616

Eesti Vabaharidusliit (2003). Eesti vabaharidusliku koolituse analüüs. Tallinn: MTÜ Eesti Vabaharidusliit. Külastatud aadressil http://www.vabaharidus.ee/index.php?page $=120$.

Elder, G. H., \& Shanahan, M. J. (2006). The life course and human development: An ecological perspective. In W. Damon \& R. M. Lerner (Eds.), Handbook of child psychology (Vol. 1, pp. 665-715). Hoboken, NJ: John Wiley \& Sons.

Field, J. (2005). Social capital and lifelong learning. Bristol: Policy Press. http://dx.doi.org/10.1332/policypress/9781861346551.001.0001

Flick, U. (2009). An introduction to qualitative research (4th ed.). London: Sage.

Halapuu, V., \& Valk, A. (2013). Täiskasvanute oskused Eestis ja maailmas. PIAAC uuringu esmased tulemused. Tartu: Haridus- ja Teadusministeerium. Külastatud aadressil http://www.oecd.org/site/piaac/Estonia.pdf.

Haridus- ja Teadusministeerium (2005). Elukestva õppe strateegia 2005-2008. Külastatud aadressil http://www.hm.ee/index.php?popup=download\&id=6877.

Helemäe, J., Saar, E., \& Vöörmann, R. (2000). Kas haridusse tasus investeerida? Hariduse selekteerivast ja stratifitseerivast rollist kahe põlvkonna kogemuse alusel. Tallinn: Teaduste Akadeemia Kirjastus.

Holford, J., Riddell, S., \& Weedon, E. (2010). Täiskasvanute õppes osalemise riikidevahelisi erinevusi mõjutavad tegurid. T. Roosalu (toim.), Kolmekesi elukestvas óppes: óppija, kool ja tööandja (lk 57-64). Tallinn: Eesti Täiskasvanute Koolitajate Assotsiatsioon Andras.

Illeris, K. (2003). Towards a contemporary and comprehensive theory of learning. International Journal of Lifelong Education, 22(4), 396-406. http://dx.doi.org/10.1080/02601370304837

Illeris, K. (2007). How we learn: Learning and non-learning in school and beyond. Oxon: Routledge.

Jarvis, P. (1998). Täiskasvanuharidus \& pidevõpe. Teooria ja praktika. Tallinn: SE \& JS. Jarvis, P. (2007). Globalisation, lifelong learning and the learning society: Sociological perspectives. New York: Routledge.

Jarvis, P. (2011). Learning: The experience of a lifetime! L. Jõgi \& K. Krabi (toim.), Raamat õppimisest. Õppides täiskasvanuks - óppimine erinevates perspektiivides (lk 28-48). Tallinn: Tallinna Ülikooli Kirjastus.

Jõgi, L. (2006). Andragoogilise, sotsiaalse ja psühholoogilise aspekti tegurite koosmõju täiskasvanute õppimiskäsitustele, õppimisvalmisolekule ja koolitusaktiivsuse kujunemisele elukestva õppe kontekstis. Uurimuse kokkuvõte. Tallinn: Tallinna Ülikool.

Kailis, E., \& Pilos, S. (2005). Lifelong learning in Europe. Statistics in focus: Population and social conditions. Retrieved from http://epp.eurostat.ec.europa.eu/cache/ITY_ OFFPUB/KS-NK-05-008/EN/KS-NK-05-008-EN.PDF. 
Kalkun, M., \& Kalvet, T. (2002). Digitaalne lõhe Eestis ja selle ületamise võimalused. Tallinn: Emor ja Poliitikauuringute Keskus PRAXIS.

Kalmus, V., \& Vihalemm, T. (2004). Eesti siirdekultuuri väärtused. V. Kalmus, M. Lauristin \& P. Pruulmann-Vengerfeldt (toim.), Eesti elavik 21. sajandi algul. Ülevaade uurimuse „Mina. Maailm. Meedia” tulemustest (lk 31-44). Tartu: Tartu Ülikooli Kirjastus.

Kattel, R., \& Kalvet, T. (2002). Majandusareng, innovatsioon ja tehnoloogilis-majanduslik paradigma: väljakutse Kesk- ja Ida-Euroopa riikidele. Riigikogu Toimetised, 5, 142-148. Külastatud aadressil

http://www.riigikogu.ee/rito/index.php?id=11739\&op=archive2.

Kennedy, M. D. (2002). Cultural formations of post-communism: Emancipation, transition, nation, and war. Minneapolis, London: University of Minnesota Press.

Kõresaar, E. (2005). Katkestus kui kogemus ja kultuur: Nõukogude okupatsiooni tõlgenduslikust repertuaarist. T. Anepaio (toim.), Elu ideoloogiad: kollektiivne mälu ja autobiograafiline minevikutõlgendus eestlaste elulugudes (lk 69-110). Tartu: Eesti Rahva Muuseum.

Lauristin, M., \& Vihalemm, P. (2009). The political agenda during different periods of Estonian transformation: External and internal factors. Journal of Baltic Studies, 40(1), 1-28. http://dx.doi.org/10.1080/01629770902722237

Märja, T. (2008). Development and state of art of adult learning and education (ALE). National report of Estonia. Retrieved from

http://www.unesco.org/fileadmin/MULTIMEDIA/INSTITUTES/UIL/confintea/ pdf/National_Reports/Europe\%20-\%20North\%20America/Estonia.pdf.

Patton, M. Q. (1990). Qualitative evaluation and research methods. Newbury Park, CA: Sage.

Perez, C. (2002). Technological revolutions and financial capital: The dynamics of bubbles and golden ages. Cheltenham: Elgar.

http://dx.doi.org/10.4337/9781781005323

Pilli, E., Sammul, M., Post, P., Aasjõe, Ü., \& Kruusamäe, K. (2013). Eesti kõrgkoolide esmakursuslaste õpi- ja teadmuskäsitus. Eesti Haridusteaduste Ajakiri, 1, 156-191. http://dx.doi.org/10.12697/eha.2013.1.08

Putnam, R. D. (2008). Üksi keeglisaalis. Ameerika kogukonnaelu kokkuvarisemine ja taassünd. Tartu: Hermes.

Quane, A. (2008). UNESCO's drive for lifelong learning. In P. Jarvis (Ed.), The Routledge international handbook of lifelong learning (pp. 302-311). London, New York: Routledge.

Reinhold, M. (2012). Täiskasvanuhariduse valdkonna statistika põhinäitajad. Tartu: Haridus- ja Teadusministeerium. Külastatud aadressil http://www.hm.ee/index.php?popup=download\&id=11930.

Riigikogu (1993). Täiskasvanute koolituse seadus. Riigi Teataja I, 18.03.2011, 8. Külastatud aadressil https://www.riigiteataja.ee/akt/118032011008.

Rubenson, K. (2004). Lifelong learning: A critical assessment of the political project. In P. Alheit et al. (Eds.), Shaping an emerging reality - researching lifelong learning (pp 28-48). Retrieved from http://s3.amazonaws.com/zanran_storage/www.ruc.dk/ContentPages/17774799.pdf. 
Schuller, T. (2001). The complementary roles of human and social capital. Canadian Journal of Policy. Retrieved from http://www.oecd.org/dataoecd/5/48/1825424.pdf.

Schuller, T. (2008). The OECD and lifelong learning. In P. Jarvis (Ed.), The Routledge international handbook of lifelong learning (pp. 292-301). London, New York: Routledge.

Statistikaamet (2009). Täiskasvanute koolitus. Adult education. Tallinn: Statistikaamet. Külastatud aadressil http://www.stat.ee/publication-download-pdf?publication_id=18392.

Sugarman, L. (2001). Life-span development: Frameworks, accounts, and strategies (2nd ed.). London: Routledge.

Tesch, R. (1990). Qualitative research. Analysis types \& software tools. London etc.: Routledge Falmer.

Titma, M. (2002). 30- ja 50-aastaste põlvkonnad uue aastatuhande künnisel. Tartu: Tartu Ülikooli Kirjastus.

Viira, A-H. (2011). Eesti põllumajanduse arenguetapid viimasel 20 aastal. R. Miljan (toim.), Maaelu arengu aruanne (lk 86-91). Tartu: Eesti Maaülikool. Külastatud aadressil

http://eesti2030.files.wordpress.com/2012/01/maaelu_arengu_aruanne_2011final.pdf.

Vogt, H. (2005). Between Utopia and disillusionment: A narrative of the political transformation in Eastern Europe. New York, Oxford: Berghahn Books.

Vöörmann, R., Helemäe, J., Saar, E., \& Kazjulja, M. (2005). Vanemaealiste töötajate konkurentsivõime ja koolitusvajadus. Tallinn: Tallinna Ülikool. Külastatud aadressil http://www.andras.ee/client/default.asp?wa_id=849\&wa_id_key. 


\title{
Middle-aged people with Soviet-era university education in the lifelong learning environment of the transition period
}

\author{
Tiiu Männiste ${ }^{\mathrm{a} 1}$ \\ ${ }^{a}$ University of Tartu, Institute of Social Studies
}

\section{Summary}

The author was inspired to write this article by the initial results of the international survey measuring adults' literacy and numeracy skills and problem-solving skills in technology-rich environments. The survey revealed that the „problem-solving skills in technology-rich environments in Estonia are below average compared to other participating countries" (Halapuu \& Valk, 2013, p. 37). A significant „contribution” to Estonia’s low result was made by middle-aged and elderly university-educated people, whose „all skills were below the average of the participating countries" (Halapuu \& Valk, 2013, p. 69).

The qualitative research conducted by the author reaches similar results, but the conclusions relying on the results of the research are based on the analysis of the culture of the transition period in Estonia, the policies of lifelong learning and the discontinuity in the trajectories of the generation's lifespan.

The article deals with the renewal of cultural capital of specialists with Soviet-era university education born at the end of the 1950s and the first half of the 1960s, during the transition era, based on the results of 12 qualitative interviews conducted in 2011. The researched group represents the generation of professionals who were strongly tied to the labour market prior to the transition period and whose important resource for success was their specialised university education that had good prospects to become the favourable seed capital in the transition period (Helemäe et al., 2000).

In the article, the renewal of cultural capital through participation in job-related continuing education and retraining is observed. In addition, it deals with the different ways and results of acquiring the basic skills of the transition period (e.g., English and computer skills).

1 Institute of Social Studies, Faculty of Social Sciences and Education, University of Tartu, Lossi 36, 51003 Tartu, Estonia; tiiu.manniste@ut.ee 
Cultural capital is analysed based on Pierre Bourdieu's theory of cultural capital and its relationship with economic capital (Bourdieu, 1984, 2003). According to Bourdieu, educational institutions, above all institutions of higher education, were among the key factors for the reproduction of social space of cultural capital (Bourdieu, 2003). As in the Soviet Union, the classical economic capital (private property) was missing, Bourdieu's "principle of distinction" operated here between the owners of cultural capital rather than economic (Bourdieu, 2003). Soviet-era higher education could be regarded as an opportunity for social distinction from agents with lower cultural capital. Bourdieu's classical distinction factors and resources in different field hierarchies (Bourdieu, 2003) can be observed in postsocialist countries starting from the transition period together with the emergence of market economy.

The transition culture of the 1990s (Kennedy, 2002), the globalisation process and ICT development (Bell, 1999; Castells, 2000; Perez, 2002) activated new functions and resources in the Bourdieuian cultural field (Bourdieu, 1984). Knowledge accumulation and information processing functions of the network society (Castells, 2000) went beyond Bourdieu's classical cultural field, blending with both the social and the economic field. "Lifelong learning", the new education paradigm that started to spread more extensively from the mid-1990s, added the combined effect of the working world and the education system to the reproduction field of cultural capital. (Centeno, 2011; Rubenson, 2004).

In the study, the interviewees' Soviet-time knowledge (formal education) and their readiness to restart learning during the transition period are considered as forms of cultural capital; the existing and newly acquired qualification as cultural assets and the lifelong learning environments of the transition period (continuing education and retraining courses) as institutions.

The author follows the interviewees' participation in the cultural field chronologically during different stages in the economic and political transformations of the transition period in Estonia from 1988 to 2008 (Lauristin \& Vihalemm, 2009). In connection with the transition period, as a specificity of post-socialist transition, the key concept "discontinuity” is used, which in the Estonian society means "lack of continuity on the political, social, cultural and empirical scale" (Kõresaar, 2005, p. 69).

The radical reforms of the early 1990s cut off mainly the developing „life course trajectory" (Elder \& Shanahan, 2006) of the young adult generation. At the beginning of the transition period the research group belonged to the generation of young adults (22-40 years) (Sugarman, 2001). 
The main research questions were the following:

- What were the possibilities for the renewal of cultural capital in the transition period?

- What kind of cultural capital was produced by the new opportunities of self-development?

- What were the learning attitudes and motivation like?

- How did the renewal of the cultural capital influence the career paths in the transition period?

The applied research method was semi-structured, or more precisely, episodic interview. In the course of 12 interviews conducted, data on the participation of interviewees in lifelong learning during the transition period were collected. With regard to the categories of the analysis, the focus was laid on the experiences described in the transcribed interviews in which learning-related situations were revealed, and the related career changes. Interviewees primarily remembered the connections between their studies and their work career, and to a lesser extent, 'learning as the process of transforming experiences' (Jarvis, 2007).

The sample choice criteria included age (born between 1955 and 1964) and university education acquired in the field of technology, agriculture, and social sciences-humanities during the Soviet period before the beginning of transition. By the beginning of the transition period the respondents had an average of 3-5 years of working experience.

Research results describe relationships between professional continuing education with career paths, the learning attitudes of different learner types and the results of acquiring primary basic skills (e.g., foreign language, computer).

Results of the research show that today's middle-aged generation with Soviet-era university education managed to remain actively engaged in employment during the transition period owing to participation in lifelong learning. Adaptation to changes was also significantly influenced by active interest in learning and good professional skills acquired in the Soviet period.

A comparison of different learner types shows that strong cultural capital can become a development trap unless it is constantly renewed. Compared to professional skills, the interviewees were not able to acquire basic transition skills (e.g., foreign language, computer skills) at a level that would provide them with competitive advantage in the digital world.

Results of the study allow to conclude that the relatively low level of infotechnological skills of university-educated middle-aged Estonian people does not result only from their limited possibilities to use ICT devices at 
work and home, modest participation in computer courses, lack of time and cost of the courses, as indicated in initial PIAAC results (Halapuu \& Valk, 2013). The causes for the low-level basic skills of middle-aged universityeducated people lie to a large extent in the transition culture (Kennedy, 2002; Lauristin \& Vihalemm, 2009), lifelong learning policies (Centeno, 2011; Quane, 2008; Rubenson, 2004) and the discontinuity in the „life course trajectory" (Elder \& Shanahan, 2006) of this generation at the beginning of the 1990s.

Keywords: post-socialist transition period, lifelong learning, learner types, life span, basic skills 